\title{
(4S)-4,8-dihydroxy-1-tetralone and other chemical constituents from Pestalotiopsis sp. EJC07, endophytic from Bauhinia guianensis
}

\author{
ELEANE M.C. DE SOUZA, ELLON L. DA SILVA, ANDREY M.R. MARINHO and PATRÍCIA S.B. MARINHO
}

Faculdade de Química, Universidade Federal do Pará, UFPA, Rua Augusto Corrêa, 01, Guamá, 66075-110 Belém, PA, Brasil

Manuscript received on July 7, 2014; accepted for publication on July 13, 2015

\begin{abstract}
The present work reports the isolation of eight compounds from Pestalotiopsis sp. EJC07 isolated as endophytic from Bauhinia guianensis, a tipical plant of the Amazon. The compounds (4S)-4,8-dihydroxy1-tetralone (1), uracil (2), uridin (3), p-hydroxybenzoic acid (4), ergosterol (5), ergosterol peroxide (6), cerevisterol (7) and ducitol (8) were isolated by chromatographic procedures and identified by spectral methods of 1D and 2D NMR and MS. The compound $\mathbf{1}$ is being reported for the first time in the genus Pestalotiopsis.
\end{abstract}

Key words: B. guianensis, endophityc fungus, Pestalotiopsis, tetralone.

\section{INTRODUCTION}

The endophytic microorganisms live in the internal tissues of plants without causing apparent diseases to their hosts (Petrini et al. 1992). In the tropical and temperate forests, covering only $1.44 \%$ of the terrestrial surface, there are approximately 300,000 (three hundred thousand) plant species so far analyzed, home to more than $60 \%$ of the world biodiversity (Strobel et al. 2004). As a result, the opportunity to find new microorganisms and producers of bioactive compounds for agriculture, industry and medicine has increased the bioprospection of this microbiota of great importance in biotechnology (Strobel 2002).

Fungi generally are characterized by rapid growth of their colonies, adapting to various culture media, mostly in cereals such as rice and corn,

Correspondence to: Patrícia Santana Barbosa Marinho

E-mail: pat@ufpa.br where their metabolism is potentiated and, still producing a wide variety of secondary metabolites with the most diverse activities (Marinho et al. 2005).

Fungi of the Pestalotiopsis genus are broadly distributed, occurring in soil, seeds, fruits and leafs, can be parasite, endophytic or saprobes (Jeewon et al. 2004). Frequently endophytic association has been described to Pestalotiopsis generally found in subtropical and tropical regions (Wei and $\mathrm{Xu}$ 2004, Strobel and Daisy 2003). There are many reports of the metabolites secondary produced by Pestalotiopsis with biological activity and biotechnological applicability (Strobel and Long 1998, Li et al. 2005).

Thus, we decided study the biomass produced by endophytic fungus Pestalotiopsis sp. EJC07 isolated from Bauhinia guianensis and this work led to the isolation of the eight known compounds 
biologically active (Figure 1). The (4S)-4,8dihydroxy-1-tetralone is being reported the first time in the Pestalotiopsis genus.

\section{MATERIALS AND METHODS}

\section{GENERAL PROCEDURES}

ESIMS data were acquired in positive and negative mode using a Waters Acquity TQD instrument. 1D and 2D NMR spectra were recorded on a Varian Mercury 300, using solvent signal as reference. The chemical shifts are given in delta $(\delta)$ values and the coupling constants $(J)$ in Hertz $(\mathrm{Hz})$.

PLANT MATERIAL

Bauhinia guianensis was collected in the city of Belém-PA and a voucher specimen (number 177.179) was deposited at the Herbarium of Empresa Brasileira de Pesquisa Agropecuária (EMBRAPA).<smiles>O=C1CC[C@H](O)c2cccc(O)c21</smiles>

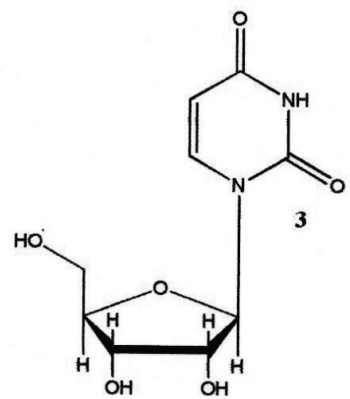<smiles></smiles><smiles>O=C(O)c1ccc(O)cc1</smiles><smiles>OC[C@@H](O)[C@@H](O)[C@H](O)[C@H](O)CO</smiles>

MICROORGANISM

Pestalotiopsis sp. was obtained from a collection of the Laboratório de Bioensaios e Química de Microorganismos (LaBQuiM), Faculdade de Química - Universidade Federal do Pará. This collection contains isolates from Bauhinia guianensis. One strain is deposited in the LaBQuiM with the code EJC07.

\section{CUlture of Pestalotiopsis sp. IN RICE AND CHEMICAL CONSTITUENTS ISOLATION}

Twenty-two Erlenmeyer flasks $(1,000 \mathrm{~mL})$ containing $200 \mathrm{~g}$ rice (Tio João ${ }^{\circledR}$ ) and $125 \mathrm{~mL}$ distilled water per flask were autoclaved for $45 \mathrm{~min}$ at $121^{\circ} \mathrm{C}$. Small cubes of PDA medium containing mycelium of Pestalotiopsis sp. EJC07 were added in 20 Erlenmeyer flasks under sterile condition. Two flasks were used as control. After 30 days of growth at $25^{\circ} \mathrm{C}$ the biomass obtained was macerated with hexane, ethyl acetate and methanol.

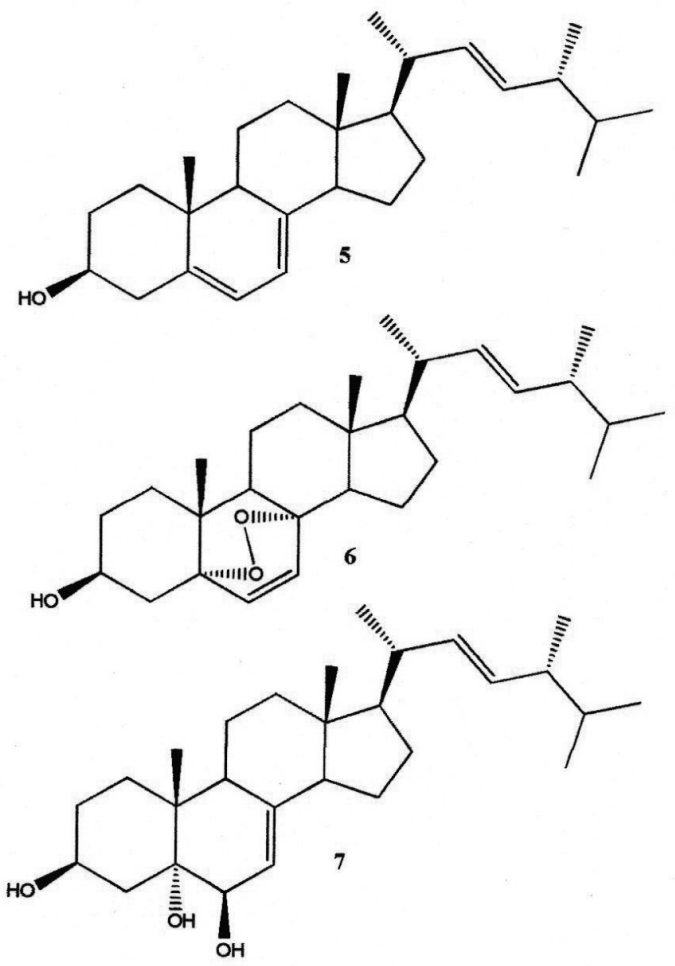

Figure 1 - Compounds isolated from Pestalotiopsis sp. EJC07. 
The ethyl acetate was evaporated under reduced pressure, producing a yellowish residue $(8.9 \mathrm{~g})$. After successive fractionations the ethyl acetate extract on silica gel chromatography column eluted with hexane, ethyl acetate and methanol in polarity gradient were obtained the compounds $\mathbf{1 - 8}$.

\section{RESULTS AND DISCUSSION}

\section{CONSTITUENTS ISOLATED}

The extract was submitted the chromatographic column on silica gel eluted with hexene, EtOAc and $\mathrm{MeOH}$ given (4S)-4,8-dihydroxy-1-tetralone (1), uracil (2), uridin (3), p-hydroxybenzoic acid (4), ergosterol (5), ergosterol peroxide (6), cerevisterol (7) and ducitol (8). All the compounds were identified by 1D and 2D NMR methods and comparison with literature data.

\section{CHEMICAL CONSTITUENTS IDENTIFICATION}

The mass spectrum $\operatorname{ESI}(+)$ to 1 showed $\mathrm{m} / z=179$ $[\mathrm{M}+\mathrm{H}]^{+}$, that together with $\mathrm{NMR}$ data allowed propose the molecular formula $\mathrm{C}_{10} \mathrm{H}_{10} \mathrm{O}_{3}$. The ${ }^{1} \mathrm{H}$ NMR spectrum to 1 showed signals characteristic to the aromatic ring at $\delta 7.49(t, 8.0 \mathrm{~Hz}, \mathrm{H}-6), \delta$ $7.02(d t, 7.8,0.9$ e $0.9 \mathrm{~Hz}, \mathrm{H}-5)$ and $\delta 6.92(d d$, 8.1 and $1.0 \mathrm{~Hz}, \mathrm{H}-7)$, a singlet signal at $\delta 12.41$ typical of the chelated hydroxyl and a double duplet signal at $\delta 4.92$ with coupling constants of 7.4 and $4.0 \mathrm{~Hz}$ attributed to the hydrogen H-4. Also was observed in the ${ }^{1} \mathrm{H}$ NMR spectrum two signals $d d d$ attributed to the diastereotopics hydrogens $\mathrm{H}-2$ at $\delta$ $3.00(17.8,8.2$ and $4.7 \mathrm{~Hz}, \mathrm{H}-2 \beta)$ and $\delta 2.65$ (17.8, 8.2 and $4.7 \mathrm{~Hz}, \mathrm{H}-2 \alpha)$, it was also observed two multiplets signals at $\delta 2.35$ and $\delta 2.19$ attributed to the hydrogens $\mathrm{H}-3 \beta$ e $\mathrm{H}-3 \alpha$, respectively.

In the ${ }^{13} \mathrm{C}$ NMR observed 10 signals to carbons, being six signals referents to the aromatic carbons $(\delta 162.7, \delta 145.8, \delta 137.0, \delta 117.8, \delta 117.3$ and $\delta 115.2$ ), one signal at $\delta 204.2$ attributed to the carbonyl carbon $(\mathrm{C}-1)$, the signal at $\delta 67.7$ was attributed to the carbinolic carbon $(\mathrm{C}-4)$ and the signals at $\delta 34.6$ and $\delta 31.2$ were attributed to the $s p^{3}$ carbons. The analysis of the specific rotation showed $[\alpha]^{\mathrm{D}}+12,6\left(\mathrm{CH}_{2} \mathrm{Cl}_{2}, 0,00116\right)$ to the compound $\mathbf{1}$. The signals were attributed in the base the HMBC, HSQC and COSY correlations. The spectral data were compared with the data described in the literature to $(4 S)$-4,8-di-hydroxi$\alpha$-tetralone and showed total similarity (Zhu et al. 2008). According Inácio et al. (2006) the (4S)-4,8di-hydroxi-1-tetralone showed antifungal activity by bioautography test against Cladosporium cladosporioides and C. sphaerospermum comparable to the standard nystatin and interesting allelopathic activity (Li et al. 2012).

The compounds $\mathbf{2 , 3}$ and $\mathbf{4}$ showed as principal characteristic two signals double doublet in the hydrogens aromatic region $(\delta 6.50-\delta 8.00)$ in their ${ }^{1} \mathrm{H}$ NMR spectra. Then, the ${ }^{1} \mathrm{H}$ and ${ }^{13} \mathrm{C}$ NMR data were compared with the literature allowing identify them as uracil (2), uridin (3) and $p$-hydroxybenzoic acid (4) (Marinho et al. 2007). The compounds $\mathbf{2}$ and $\mathbf{3}$ are nitrogenous bases and show antiviral activity (Pinto et al. 2002).

The compounds 5, 6 and 7 showed in their ${ }^{1} \mathrm{H}$ NMR spectra characteristics to steroidal compounds as the signals singlet and double duplet in the methyl region at 0.60 to $\delta 1.20$; methylene hydrogens signals at $\delta 1.20$ to $\delta 2.00$; signals to carbinolic hydrogens at $\delta 3.63(\mathrm{~m})$ to $\mathbf{5}, \delta 3.95(\mathrm{~m})$ to 6 and $\delta 3.61(\mathrm{~m})$ and $\delta 4.07(\mathrm{~m})$ to 7 ; further the signals to olefinics hydrogens at $\delta 5.15$ to $\delta$ 5.20. These data together with ${ }^{13} \mathrm{C}$ NMR data to the compounds allowed identify them as the steroids ergosterol (5), ergosterol peroxide (6) and cerevisterol (7) (Marinho et al. 2009). The steroid ergosterol and ergosterol peroxide have significant anticancer activity (Kawagishi et al. 1988). Already the compound $\mathbf{8}$ showed only signals to carbinolic hydrogens in their ${ }^{1} \mathrm{H}$ NMR spectrum. The comparison the ${ }^{1} \mathrm{H}$ and ${ }^{13} \mathrm{C}$ data of the 8 with the literature allowed identify as ducitol (Marinho et al. 2007).

The chemical study of the endophytic fungus Pestalotiopsis sp. EJC07 led to the isolation of eight 
biologically active compounds and the (4S)-4,8-dihydroxi-1-tetralone is being reported for the first time in the genus Pestalotiopsis. This compound have been isolated of other fungi such as Sclerotinia sclerotiorum (Morita and Aoki 1974), Cytospora eucalypticola (Kokubun et al. 2003), Caryospora callicarpa (Zhu et al. 2008), Aspergillus fumigatus (Li et al. 2012) and Paraconiothyrium variabile (Prado et al. 2013) and from plants belonging to the family Juglandaceae (Li et al. 2014, Talapatra et al. 1988). (4S)-4,8-dihydroxy-1-tetralone, a dihydronaphthalenone, has a particular interest as building blocks for more complex natural compounds featuring a spirobisnaphthalene structure (Prado et al. 2013).

\section{ACKNOWLEDGMENTS}

The authors thank the Fundação Amazônia de Amparo a Estudos e Pesquisas do Pará (FAPESPA), Conselho Nacional de Desenvolvimento Científico e Tecnológico (CNPq) and Coordenação de Aperfeiçoamento de Pessoal de Ensino Superior (CAPES) for the financial support, Secretaria de Estado de Educação do Pará (SEDUC) for the research scholarship.

\section{RESUMO}

O presente trabalho reporta o isolamento de oito compostos de Pestalotiopsis sp. EJC07 isolado como endofítico de Bauhinia guianensis, uma planta típica da Amazônia. Os compostos (4S)-4,8-diidroxi-1-tetralona (1), uracila (2), uridina (3), ácido $p$-hidroxibenzoico (4), ergosterol (5), peróxido de ergosterol (6), cerevisterol (7) e ducitol (8) foram isolados por procedimentos cromatográficos e identificados por métodos espectrais de RMN 1D e 2D e EM. O composto 1 está sendo reportado pela primeira vez no gênero Pestalotiopsis.

Palavras-chave: B. guianensis, fungo endofítico, Pestalotiopsis, tetralona.

\section{REFERENCES}

InÁcio ML, Silva GH, Teles HL, Trevisan HC, CAVALHEIRO AJ, BOLZANI VS, YOUNG MCM, PFENNING
LH AND ARAÚJO AR. 2006. Antifungal metabolites from Colletotrichum gloeosporioides, an endophytic fungus in Cryptocarya mandioccana Nees (Lauraceae). Biochem Syst Ecol 34: 822-824.

JEEWON R, LIEW ECY AND HYDE KD. 2004. Phylogenetic evaluation of species nomenclature of Pestalotiopsis in relation to host association. Fungal Divers 17: 39-55.

KAWAGISHI H, KATSUMI R, SAZAWA T, MIZUNO T, HAGIWARA T AND NAKAMURA T. 1988. Cytotoxic Steroids from the Mushroom Agaricus blazei. Phytochemistry 27: 27772779.

KOKUBUn T, VEITCH NC, BRIDGE PD AND SIMMONDS MSJ. 2003. Dihydroisocoumarins and a tetralone from Cytospora eucalypticola. Phytochemistry 62: 779-782.

LI H, QING C, ZHANG Y AND ZAHO Z. 2005. ScreenIng for endophytic fungi with antitumour and antifungal activities from Chinese medicinal plants. World J Microbiol Biotechnol 21: 1515-1519.

LI XJ, ZHANG Q, ZHANG AL AND GAO JM. 2012. Metabolites from Aspergillus fumigatus, an endophytic fungus associated with Melia azedarach, and their antifugal, antifeedant, and toxic activities. J Agric Food Chem 60: 3424-3431.

LI XX, YU MF, RUAN X, ZHANG YZ AND WANG Q. 2014. Phytotoxicity of 4,8-dihydroxy-1-tetralone isolated from Carya cathayensis Sarg. to various plant species. Molecules 19: 15452-15467.

MARINHO AMR, RODRIGUES-FILHO E, MOITINHO MLR AND SANTOS LS. 2005. Biologically active polyketides produced by Penicilium janthinellum isolated as an endophytic fungus fruit of Melia azedarach. J Braz Chem Soc 16: 280-283.

MARINHO AMR, MARINHO PSB AND RODRIGUES FILHO E. 2007. Constituintes Químicos de Penicillium sp, um Fungo Endofítico Isolado de Murraya paniculata (Rutaceae). RECEN 9: 189-199.

MARINHO AMR, MARINHO PSB AND RODRIGUES FILHO E. 2009. Esteroides produzidos por Penicillium herquei, um fungo endofítico isolado dos frutos de Melia azedarach (Meliaceae). Quim Nova 32: 1710-1712.

MORITA T AND AOKI H. 1974. Isosclerone, a new metabolite of Sclerotinia sclerotiorum (LIB.) De Bary. Agric Biol Chem 50: 997-1001.

Prado S, Buisson D, Ndoye I, VALlet M AND NAY B. 2013. One-step enantioselective synthesis of (4S)isosclerone through biotranformation of juglone by an endophytic fungus. Tetrahedron Lett 54: 1189-1191.

Petrini O, Sieber TN, TOTI L AND Viret O. 1992. Ecology, metabolite production, and substrate utilization in endophytic fungi. Natural Toxins 1: 185-196.

PINTO AC, SILVA DHS, BOLZANI VS, LOPES NP AND EPIFANIO RA. 2002. Produtos naturais: atualidade, desafios e perspectivas. Quim Nova 25: 45-61. 
STROBEL G AND DAISY B. 2003. Bioprospecting for microbial endophytes and their natural products. Microbiol Mol Biol Rev 67: 491-502.

STROBEL GA. 2002. Rainforest endophytes and bioactive products. Crit Rev Biotechnol 22: 315-333.

Strobel GA, DAisy B, CASTILlo U AND HARPER J. 2004. Natural Products from Endophytic Microorganisms. J Nat Prod 67: 257-268.

STROBEL GA AND LONG DM. 1998. Endophytic microbes embody pharmaceutical potential. ASM News 64: 263268.
TALAPATRA SK, KARMACHARYA B, DE SC AND TALAPATRA B. 1988. (-)-regiolone, an $\alpha$-tetralone from Juglans regia: structure, stereochemistry and conformation. Phytochemistry 27: 3929-3932.

WEI JG AND XU T. 2004. Pestalotiopsis kunmingensis, sp. nov., an endophyte from Podocarpus macrophyllus. Fungal Divers 15: 247-254.

ZHU Y, DONG J, WANG L, ZHOU W, LI L, HE H, LIU H AND ZHANG K. 2008. Screening and isolation of antinematodal metabolites against Bursaphelenchus xylophilus prodiced by fungi. Ann Microbiol 58: 375-380. 